\title{
BACTÉRIAS ENDOFÍTICAS COMOAGENTES PROMOTORES DO CRESCIMENTO DE PLANTAS DE TOMATEIRO E DE INIBIÇÃO IN VITRO DE Ralstonia solanacearum ${ }^{1}$
}

\author{
Endophytic bacteria as agents of plant growth promotion in tomato and inhibition \\ in vitro of Ralstonia solanacearum
}

Patrícia Baston Barretti², Ricardo Magela de Souza², Edson Ampélio Pozza²

\begin{abstract}
RESUMO
A partir de 150 isolados de bactérias endofíticas obtidos de folhas, caules e raízes de tomateiros sadios, 53 destacaram-se quanto à habilidade em promover o crescimento de plantas de tomateiro (Solanum lycopersicum L.). Submetidos a uma nova seleção, os isolados UFV-E17, UFV-E22, UFV-E25, UFV-E26, UFV-E27, Bacillus cereus (UFV-E29), UFV-E49, UFLA 06-LS, UFLA 08-LS e UFLA 11-LS apresentaram maior promoção do crescimento. Avaliações semanais de altura e número de folhas e folíolos das plantas aconteceram durante 45 dias. Após a sexta avaliação, mensurou-se a área foliar e o peso da matéria fresca e seca da parte aérea e da raiz das plantas. O isolado UFV-E49 apresentou melhor resultado para altura, área foliar, número de folhas e peso da matéria fresca e seca, tanto da parte aérea quanto da raiz. Dos isolados selecionados, somente dois apresentaram efeito inibitório direto in vitro a Ralstonia solanacearum.
\end{abstract}

Termos para indexação: Endófitas, tomate, fixação de nitrogênio, Ralstonia solanacearum, Solanum lycopersicum.

\section{ABSTRACT}

Out of one hundred and fifty isolates of endophytic bacteria from leaves, stems and roots of healthy tomatoes (Solanum lycopersicum L.), fifty three showed ability to promote tomato plant growth, among these, ten isolates UFV-E17, UFV-E22, UFVE25, UFV-E26, UFV-E27, Bacillus cereus (UFV-E29), UFV-E49, UFLA 06-LS, UFLA 08-LS and UFLA 11-LS, provided the largest plant growth promotion. Weekly assessment of plant height and number of leaves and leaflets were carried out during 45 days. After the sixth evaluation, the leaf area and the fresh and dry weight of the aerial part of plants and of the roots were measured. Isolate UFVE49 provided the largest values of height, leaf area, number of leaves and fresh and dry weight of the aerial part of plants as well as the root. From the selected isolates, only two presented antimicrobial activity against Ralstonia solanacearum.

Index terms: Endophytes, tomato, nitrogen fixation, Ralstonia solanacearum, Solanum lycopersicum.

\section{(Recebido em 31 de janeiro de 2006 e aprovado em 7 de agosto de 2006)}

\section{INTRODUÇÃO}

A teoria de que bactérias não patogênicas residem em tecidos de plantas foi formulada por Perotti em 1926 (HALLMANN et al., 1997). Porém, estudos sobre a colonização de tecidos internos de plantas sadias por bactérias datam de 1870, com os trabalhos de Pasteur e outros pesquisadores (HOLLIS, 1951). Os primeiros relatos consideraram as bactérias endofíticas como contaminantes resultantes da desinfestação superficial incompleta ou como patógenos fracamente virulentos (HOLLIS, 1951). Entretanto, pesquisas recentes demonstraram que bactérias endofíticas podem promover o crescimento das plantas e reduzir os sintomas de doenças causadas por diversos patógenos (HALLMANN et al., 1997).

Segundo Sturtz (1995), aproximadamente $10 \%$ das bactérias endofíticas isoladas de tubérculos de batata promoveram o crescimento das plantas. De forma semelhante, a introdução do isolado BH72 da bactéria endofítica diazotrófica Azoarcus sp. em plantas de arroz resultou em crescimento significativo das plantas (HUREK et al., 1994).

Os efeitos na promoção de crescimento incluem aumentos na altura, na biomassa da parte aérea, do caule e da raiz e na formação de pêlos radiculares e foliares da planta, na lignificação de vasos do xilema e na produção de tubérculos em batata (PILLAY \& NOWAK, 1997; STURTZ, 1995).

Os principais mecanismos pelos quais as bactérias endofíticas promovem o crescimento de plantas são a fixação de nitrogênio (BODDEY \& DOBEREINER, 1995) e o controle biológico de fitopatógenos, seja este pelo antagonismo direto da microflora deletéria ou pela indução de resistência sistêmica (HALLMANN et al., 1997). No

\footnotetext{
${ }^{1}$ Parte da tese apresentada à Universidade Federal de Lavras/UFLA - Lavras, MG, pela primeira autora para obtenção do título de Doutora em Agronomia/ Fitopatologia.

${ }^{2}$ Doutores em Fitopatologia - Departamento de Fitopatologia/DFP - Universidade Federal de Lavras/UFLA - Cx. P. 3037 - $37200-000$ - Lavras, MG patriciabaston@hotmail.com; rmagelas@ufla.br; eapozza@ufla.br
} 
entanto, as bactérias endofíticas podem também promover o crescimento de plantas pela produção de hormônios vegetais ou de substâncias análogas (ARSHAD \& FRANKENBERGER, 1991).

Com relação às doenças, as bactérias endofíticas mostraram-se eficientes agentes de biocontrole de diversos patógenos, tanto de origem fúngica quanto bacteriana (HALLMANN et al., 1997). Dentre eles, Ralstonia solanacearum (Smith) Yabuuchi et al., agente causal da murcha bacteriana do tomateiro (Solanum lycopersicum L.) (BARRETTI, 2001; NASCIMENTO, 1998).

Assim, conduziu-se este trabalho, com os objetivos de avaliar a capacidade de dez isolados previamente selecionados em promover o crescimento de plantas de tomateiro, bem como averiguar os possíveis mecanismos envolvidos na promoção de crescimento.

\section{MATERIAL E MÉTODOS}

Parte dos isolados de bactérias endofíticas foi obtida no Laboratório de Bacteriologia de Plantas da Universidade Federal de Viçosa (UFV) e parte no Laboratório de Bacteriologia Vegetal da Universidade Federal de Lavras (UFLA).

Os experimentos foram desenvolvidos em casa-devegetação e nos Laboratórios de Bacteriologia Vegetal e Microbiologia do Solo, dos Departamentos de Fitopatologia e Ciência do Solo e instalados na Universidade Federal de Lavras (UFLA), Lavras, MG.

\section{Isolamento de bactérias endofíticas de folhas e caules de tomateiro}

Folhas e caules das plantas de tomateiro aparentemente sadias, coletadas em plantios convencionais e hortas orgânicas nos municípios de Lavras, Ribeirão Vermelho, Ijaci, Bom Sucesso, Nepomuceno, Três Pontas e Viçosa, Minas Gerais, foram lavadas em água de torneira e enxugadas com papel absorvente. Em seguida, foi feita a desinfestação superficial com álcool 50\%, por 1 minuto, hipoclorito de sódio $2 \%$, por 6 minutos e lavagem em água destilada esterilizada, por três vezes. Os fragmentos do tecido foram macerados em água estéril e o macerado deixado em repouso por 15 minutos, para a difusão das bactérias para a solução (ROMEIRO, 2001). Após esse período, as suspensões bacterianas obtidas foram semeadas, pelo método de estrias paralelas, em placas contendo o meio 523 de Kado \& Heskett (1970) e incubadas a $28^{\circ} \mathrm{C}$. Foram preparadas cinco placas por fragmento. Todas as colônias obtidas foram repicadas para tubos de ensaio, contendo o meio 523.
Para se confirmar a natureza endofítica dos isolados, utilizou-se o método descrito por Assis et al. (1998), porém, com modificações. O fragmento de planta, após a terceira lavagem do processo de desinfestação, foi seccionado em duas partes. Uma delas foi macerada, conforme já descrito, e a outra foi mergulhada rapidamente em tubo de ensaio contendo o meio 523 líquido e imediatamente retirada. $\mathrm{O}$ material no tubo de ensaio também foi incubado a $28^{\circ} \mathrm{C}$ e observado, a fim de se comprovar a ausência de crescimento de organismos epifíticos. Não havendo crescimento bacteriano nesses tubos de ensaio, os isolados obtidos pela maceração dos tecidos foram considerados endofíticos.

\section{Isolamento de bactérias endofíticas de raízes de tomateiro}

As raízes foram cuidadosamente lavadas em água de torneira, transferidas para frascos contendo solução tampão fosfato-potássio (PB) 0,02M esterilizada (pH 7,0) e submetidas à agitação vigorosa em agitador orbital por 1 hora. Essa operação foi repetida por quatro vezes, após a troca da solução PB. Em seguida, procedeu-se a desinfestação superficial das raízes com álcool $50 \%$ por 30 segundos e hipoclorito de sódio $1 \%$ por 3 minutos, seguida de três lavagens em solução PB esterilizada. Para desalojar da superfície do material vegetal as bactérias epifíticas remanescentes, as raízes foram transferidas para frascos contendo solução PB 0,02M esterilizada $(\mathrm{pH} 7,0)$ e submetidas a banho de ultra-som por 10 minutos. Nova desinfestação superficial das raízes foi feita em hipoclorito de sódio $1 \%$ por 3 minutos, seguida de três lavagens em solução PB esterilizada. A seguir, as raízes foram transferidas para frascos com solução PB esterilizada e submetidas a novo banho de ultra-som por 10 minutos.

A trituração das raízes foi feita em almofariz e pistilo esterilizados contendo PB e o triturado novamente submetido a banho de ultra-som por 10 minutos, desta vez para desagregação das partículas e células bacterianas. Procedeu-se a diluição em série em solução PB com fator diluição 1:10. Alíquotas de $100 \mu \mathrm{l}$ das diluiçõos $10^{-1}, 10^{-2}$, $10^{-3}$ foram retiradas e transferidas para placas de Petri contendo meio "Tryptic Soy Agar" (TSA) (Difco) e espalhadas com alça de Drigalsky. Foram preparadas cinco placas por diluição, que foram incubadas a $28^{\circ} \mathrm{C}$ durante 48 horas. Após esse tempo, as colônias bacterianas foram transferidas para tubos de ensaio contendo o meio TSA.

Para confirmar a natureza endofítica dos isolados, $100 \mu$ da solução de PB utilizada após o segundo banho de ultra-som foram transferidas para placas de Petri, contendo o meio TSA e incubadas nas mesmas condições para as placas preparadas com as diluições dos triturados. Não 
havendo crescimento bacteriano nessas placas dentro de 48 horas, os isolados obtidos pela trituração das raízes foram considerados endofíticos (NAVES et al., 2004).

\section{Cultivo e preservação das culturas bacterianas obtidas}

As culturas bacterianas foram cultivadas em meio 523 e preservadas em peptona-glicerol a $-80^{\circ} \mathrm{C}$. Para o uso experimental, as bactérias endofíticas foram transferidas para placas de Petri contendo meio 523 e incubadas a $28^{\circ} \mathrm{C}$ em câmara de crescimento. Após 48 horas, foram preparadas as suspensões bacterianas, adicionando-se água de torneira e homogeneizando-se com a alça de Drigalsky.

\section{Introdução das bactérias endofíticas em plantas de tomateiro}

A técnica eleita foi o corte do hipocótilo, descrita e patenteada por Kijima et al. (1995). Plântulas de tomateiro cv. Santa Clara, cultivadas em bandejas de isopor, contendo o substrato Plantmax ${ }^{\circledR}$, foram seccionadas na região do hipocótilo quando apresentavam o segundo par de folhas definitivas. O sistema radicular foi descartado e o restante da planta imerso por seis horas, em suspensão de células de cada bactéria endofítica ajustada ao espectrofotômetro para $\mathrm{A}_{540}=0,2$. Posteriormente, as seções da parte aérea foram plantadas em vasos de $3 \mathrm{~kg}$ de capacidade, contendo a mistura de solo, areia e esterco $(2: 1: 1)$ previamente fumigada com brometo de metila e permaneceram em casade-vegetação até o término do experimento.

\section{Seleção de bactérias endofíticas com potencial para promover o crescimento de plantas e controlar a murcha bacteriana do tomateiro em casa-de-vegetação}

Pela dificuldade em avaliar cento e cinqüenta isolados de uma só vez, eles foram divididos e testados em quatro baterias distintas, empregando-se 57 isolados na primeira bateria e 31 nas demais.

Na primeira bateria, o delineamento experimental foi inteiramente casualizado com 58 tratamentos, cinco repetições e duas plantas por parcela. Os tratamentos foram constituídos por 57 isolados endofíticos e uma testemunha tratada com água destilada esterilizada (testemunha absoluta). Na segunda, terceira e quarta baterias, o delineamento experimental foi inteiramente casualizado com 32 tratamentos, cinco repetições e duas plantas por parcela. Os tratamentos foram constituídos por 31 isolados endofíticos e uma testemunha absoluta.

Para avaliar a promoção de crescimento das plantas, mediu-se a altura do ponto de inserção das folhas cotiledonares até o ápice, dez dias após a introdução das endofíticas.
Nova seleção entre os isolados de bactérias endofíticas com potencial para promover o crescimento de plantas de tomateiro em casa-de-vegetação

Os isolados de bactérias endofíticas que proporcionaram aumento significativo da altura das plantas em relação à testemunha foram submetidos a nova seleção em uma única bateria. $\mathrm{O}$ delineamento experimental foi blocos casualizados com 54 tratamentos, quatro repetições e duas plantas por parcela. Os tratamentos foram constituídos de 53 isolados e uma testemunha absoluta. A avaliação da altura das plantas foi realizada conforme descrito acima.

Avaliação do potencial de promoção de crescimento de tomateiro por isolados de bactérias endofíticas previamente selecionados

Os isolados endofíticos que proporcionaram as maiores alturas foram selecionados para testes posteriores. O delineamento experimental foi blocos casualizados, com 11 tratamentos, quatro repetições e duas plantas por parcela. Os tratamentos foram constituídos de dez isolados e uma testemunha absoluta.

As avaliações iniciaram-se 10 dias após a introdução das bactérias endofíticas em plântulas de tomateiro e aconteceram semanalmente, durante 45 dias, nas quais foram mensuradas a altura e o número de folhas e folíolos das plantas. Após o término da sexta avaliação, mensurou-se o peso de matéria fresca e seca da parte aérea e da raiz e a área foliar das plantas.

\section{Matéria fresca, área foliar e matéria seca das plantas}

Ao término das avaliações de altura e do número de folhas e folíolos, as plantas foram colhidas e separadas em parte aérea e raízes. Em seguida, as partes aéreas foram pesadas em balança eletrônica e as raízes cuidadosamente lavadas em água corrente e em água destilada, secas com papel absorvente e pesadas. Posteriormente, foram acondicionadas em sacos de papel.

Após a obtenção do peso de matéria fresca, as folhas foram cuidadosamente destacadas e digitalizadas. Suas imagens foram processadas com o programa Quant v. 1.0.1 (VALE et al., 2003), obtendo-se a área foliar total de cada planta em $\mathrm{cm}^{2}$.

Após a obtenção da área foliar, a parte aérea das plantas de tomateiro foi cuidadosamente lavada em água corrente e em água destilada, acondicionada em sacos de papel e seca em estufa $\left(70^{\circ} \mathrm{C}\right)$ até atingir peso constante. $\mathrm{O}$ mesmo procedimento de secagem foi empregado para as raízes. Em seguida, procedeu-se a pesagem do material, tanto da parte aérea quanto das raízes. 


\section{Detecção de atividade in vitro das bactérias endofíticas selecionadas sobre Ralstonia solanacearum}

Os isolados de bactérias endofíticas previamente selecionados foram cultivados em meio 523 líquido por 24 horas a $28^{\circ} \mathrm{C}$, transferidos para placas de Petri com meio 523 sólido em quatro pontos eqüidistantes e incubados por 48 horas a $28^{\circ} \mathrm{C}$. Em seguida, as placas foram invertidas e, em cada tampa, adicionou-se $1 \mathrm{ml}$ de clorofórmio para matar as colônias. Após 30 minutos, as placas foram entreabertas e deixadas por mais 30 minutos para a completa evaporação do clorofórmio. A seguir, adicionou-se uma sobrecamada de $5 \mathrm{ml}$ de meio 523 semi-sólido fundente, contendo $100 \mu \mathrm{l}$ da suspensão de $R$. solanacearum. Foram preparadas cinco placas para cada isolado. Após a incubação a $28^{\circ} \mathrm{C}$ por 48 horas, as placas de Petri foram examinadas à procura de halos de inibição indicadores de antibiose (ROMEIRO, 2001).

\section{Avaliação da capacidade das bactérias endofíticas selecionadas em fixar nitrogênio $\left(\mathbf{N}_{2}\right)$}

Fragmentos de colônias puras dos isolados endofíticos foram inoculados no centro do meio de cultura semi-sólido, sem nitrogênio e semi-específico para o diazotrófico desejado, ou seja, os meios JNFb, NFb e FAM, para Herbaspirillum sp., Azospirillum sp., e A. amazonense, respectivamente (DOBEREINER et al., 1995). Foram preparados três frascos para cada isolado, os quais foram incubados a $28^{\circ} \mathrm{C}$ por 10 dias. $\mathrm{O}$ crescimento bacteriano foi avaliado observando-se a presença ou ausência de uma película formada nos meios de cultura.

\section{Análise Estatística}

Os dados de altura, número de folhas e folíolos, área foliar, peso de matéria fresca e seca, tanto da parte aérea quanto da raiz das plantas foram submetidos à análise de variância, no programa SISVAR (FERREIRA, 2000). As médias entre os tratamentos foram agrupadas pelo teste $\mathrm{F}$, a 5\% de probabilidade. As variáveis, cujos efeitos de tratamentos foram significativos, foram submetidas ao teste Scott-Knott.

\section{RESULTADOS E DISCUSSÃO}

Seleção de bactérias endofíticas com potencial para promover 0 crescimento de plantas de tomateiro

Durante a seleção de bactérias endofíticas com potencial para controlar a murcha bacteriana, realizada em quatro baterias distintas, observou-se que 53 isolados promoveram o crescimento do tomateiro em relação à testemunha inoculada com água (Tabela 1).
Quando estes isolados foram submetidos à nova seleção, realizada em uma única bateria, dez isolados proporcionaram aumento significativo da altura das plantas em relação à testemunha (Tabela 2). Destes, os isolados UFV-E17 e UFLA 06-LS também promoveram a inibição de R. solanacearum (Tabela 2 ).

Barretti (2001) verificou em plantas de tomate tratadas com o isolado UFV-E13 crescimento maior em relação às plantas não tratadas com a bactéria endofítica. De forma semelhante, Silva (2004) observou que a altura de plantas de tomateiro foi afetada pela introdução de algumas bactérias endofíticas, sendo que Acinetobacter johnsonii e Bacillus pumilus promoveram a maior altura das plantas em $9,5 \%$ e $20,2 \%$, respectivamente.

Avaliação do potencial de promoção de crescimento de tomateiro por isolados de bactérias endofíticas

O efeito dos isolados endofíticos na promoção de crescimento variou em função das variáveis avaliadas (Tabela 3). Estes isolados foram estatisticamente superiores à testemunha, exceto para a variável número de folíolos (NFL), que não diferiu entre os tratamentos. Os isolados UFV-E17, UFV-E27 e Bacillus. cereus (UFV-E29) apresentaram PMSr 10\%, 15\% e 15\%, respectivamente, inferiores ao da testemunha (100\%).

De maneira geral, os maiores incrementos foram proporcionados pelo isolado UFV-E49, cujos aumentos na altura (ALT), área foliar (AF), número de folhas (NF), peso da matéria fresca (PMFa) e seca da parte aérea (PMSa), peso da matéria fresca (PMFr) e seca das raízes (PMSr) foram 23,40\%, 105,80\%, 19,53\%, 42,40\%, 61,64\%, $100 \%$ e $225 \%$, respectivamente, maiores do que a testemunha (100\%). Este isolado não diferiu do UFLA 11-LS para os parâmetros ALT e NF (Tabela 3). Frommel et al. (1991) verificaram que o isolado não fluorescente de Pseudomonas sp., PsJN, induziu aumento significativo no número de raízes de batateira $(24 \%$ a $196 \%)$, no peso de matéria seca de raiz ( $44 \%$ a $211 \%)$, no comprimento do caule ( $26 \%$ a $28 \%$ ), na formação de pêlos foliares $(55 \%$ a $110 \%)$ e no conteúdo total de lignina (43\%).

De maneira semelhante, Chanway (1997) obteve aumentos de $33 \%$ e $57 \%$ na biomassa de plântulas de pinheiro tratadas com os isolados PW2 e SM3-RN de Bacillus polymyxa e Pseudomonas chloroaphis, respectivamente. $\mathrm{O}$ autor também relatou aumentos na altura e no comprimento de raízes das plântulas inoculadas com estes isolados variando entre $23 \%$ e $132 \%$. 
Tabela 1 - Altura de plantas de tomateiro previamente tratadas com diferentes isolados de bactérias endofíticas.

\begin{tabular}{|c|c|c|c|c|}
\hline \multirow[t]{2}{*}{ Isolados } & \multicolumn{4}{|c|}{ Altura (cm) } \\
\hline & $1^{\circ}$ Ensaio & $2^{\circ}$ Ensaio & $3^{\circ}$ Ensaio & $4^{\circ}$ Ensaio \\
\hline UFV-E02 & $7,75 \mathrm{~d}^{1}$ & - & - & - \\
\hline UFV-E06 & $7,34 \mathrm{~d}$ & - & - & - \\
\hline UFV-E10 & $6,99 \mathrm{~d}$ & - & - & - \\
\hline UFV-E13 & $7,87 \mathrm{~d}$ & - & - & - \\
\hline UFV-E14 & $7,33 \mathrm{~d}$ & - & - & - \\
\hline UFV-E15 & $7,41 \mathrm{~d}$ & - & - & - \\
\hline UFV-E17 & $8,57 \mathrm{c}$ & - & - & - \\
\hline UFV-E21 & $8,39 \mathrm{c}$ & - & - & - \\
\hline UFV-E22 & $8,45 \mathrm{c}$ & - & - & - \\
\hline UFV-E24 & $7,72 \mathrm{~d}$ & - & - & - \\
\hline UFV-E25 & $10,55 \mathrm{a}$ & - & - & - \\
\hline UFV-E26 & $10,94 \mathrm{a}$ & - & - & - \\
\hline UFV-E27 & $8,79 \mathrm{c}$ & - & - & - \\
\hline UFV-E28 & $7,94 \mathrm{~d}$ & - & - & - \\
\hline B. cereus (UFV-E29) ${ }^{2}$ & $8,99 \mathrm{c}$ & - & - & - \\
\hline UFV-E31 & $7,64 \mathrm{~d}$ & - & - & - \\
\hline UFV-E33 & $6,96 \mathrm{~d}$ & - & - & - \\
\hline UFV-E35 & $6,94 \mathrm{~d}$ & - & - & - \\
\hline UFV-E37 & $6,14 \mathrm{e}$ & - & - & - \\
\hline UFV-E39 & $6,41 \mathrm{e}$ & - & - & - \\
\hline UFV-E40 & 6,15 e & - & - & - \\
\hline UFV-E42 & $6,38 \mathrm{e}$ & - & - & - \\
\hline UFV-E45 & $9,23 \mathrm{c}$ & - & - & - \\
\hline UFV-E48 & $7,75 \mathrm{~d}$ & - & - & - \\
\hline UFV-E49 & $11,07 \mathrm{a}$ & - & - & - \\
\hline UFV-E51 & $9,46 \mathrm{~b}$ & - & - & - \\
\hline UFV-E53 & $6,26 \mathrm{e}$ & - & - & - \\
\hline UFV-E54 & $8,01 \mathrm{~d}$ & - & - & - \\
\hline UFV-E57 & $6,99 \mathrm{~d}$ & - & - & - \\
\hline UFLA 01-LS & - & $7,24 \mathrm{c}$ & - & - \\
\hline UFLA 02-LS & - & $8,53 \mathrm{~b}$ & - & - \\
\hline UFLA 03-LS & - & $7,8 \mathrm{c}$ & - & - \\
\hline UFLA 04-LS & - & $8,89 \mathrm{~b}$ & - & - \\
\hline UFLA 07-LS & - & $11,64 \mathrm{a}$ & - & - \\
\hline UFLA 08-LS & - & $7,84 \mathrm{c}$ & - & - \\
\hline UFLA 09-LS & - & $8,37 \mathrm{~b}$ & - & - \\
\hline UFLA 11-LS & - & $8,13 \mathrm{~b}$ & - & - \\
\hline
\end{tabular}


Tabela 1-Continuação...

\begin{tabular}{lcccc}
\hline UFLA 31-TP & - & $7,66 \mathrm{c}$ & - & - \\
UFLA 48-TP & - & - & $8,04 \mathrm{a}$ & - \\
UFLA 51-TP & - & - & $7,92 \mathrm{a}$ & - \\
UFLA 54-TP & - & - & $8,45 \mathrm{a}$ & - \\
UFLA 55-TP & - & - & $7,74 \mathrm{a}$ & - \\
UFLA 56-TP & - & - & $9,08 \mathrm{a}$ & - \\
UFLA 57-TP & - & - & $7,81 \mathrm{a}$ & - \\
UFLA 67-IJ & - & - & $7,90 \mathrm{a}$ & $7,82 \mathrm{a}$ \\
UFLA 73-IJ & - & - & - & $8,74 \mathrm{a}$ \\
UFLA 81-IJ & - & - & - & $7,98 \mathrm{a}$ \\
UFLA 82-IJ & - & - & - & $9,08 \mathrm{a}$ \\
UFLA 83-IJ & - & - & - & $8,02 \mathrm{a}$ \\
UFLA 84-IJ & - & - & - & $8,12 \mathrm{a}$ \\
UFLA 87-IJ & - & - & - & $7,92 \mathrm{a}$ \\
UFLA 97-BS & - & - & $7,69 \mathrm{~b}$ & $7,20 \mathrm{~b}$ \\
UFLA 106-RV & - & - & $6,41 \mathrm{~d}$ & - \\
\hline Testemunha & $6,07 \mathrm{f}$ & & - & - \\
\hline
\end{tabular}

${ }^{1}$ Médias seguidas por letras distintas na coluna diferem entre si, pelo teste Scott-Knott, a 5\% de probabilidade ${ }^{2}$ Isolado identificado pela análise do perfil de ácidos graxos da membrana bacteriana.

Tabela 2 - Altura de plantas de tomateiro tratadas com isolados de bactérias endofíticas após a segunda seleção e efeito dos isolados sobre Ralstonia solanacearum (in vitro).

\begin{tabular}{|c|c|c|}
\hline Isolados & Altura $(\mathrm{cm})$ & Inibição in vitro à $R$. solanacearum \\
\hline UFV-E49 & $21,26 \mathrm{a}^{1}$ & - \\
\hline UFV-E25 & $20,31 \mathrm{a}$ & - \\
\hline UFLA 08-LS & $20,27 \mathrm{a}$ & - \\
\hline UFV-E27 & $18,71 \mathrm{a}$ & - \\
\hline UFV-E26 & $18,40 \mathrm{a}$ & - \\
\hline B. cereus & $18,38 \mathrm{a}$ & - \\
\hline UFV-E22 & $18,16 \mathrm{a}$ & - \\
\hline UFV-E17 & $17,95 \mathrm{a}$ & + \\
\hline UFLA 06-LS & $17,24 \mathrm{a}$ & + \\
\hline UFLA 11-LS & $17,17 \mathrm{a}$ & - \\
\hline Testemunha & $16,11 \mathrm{~b}$ & \\
\hline
\end{tabular}

(+): Presença de halo de inibição; (-): Ausência de halo de inibição

${ }^{1}$ Médias seguidas por letras distintas na coluna diferem entre si, pelo teste Scott-Knott, a 5\% de probabilidade. 


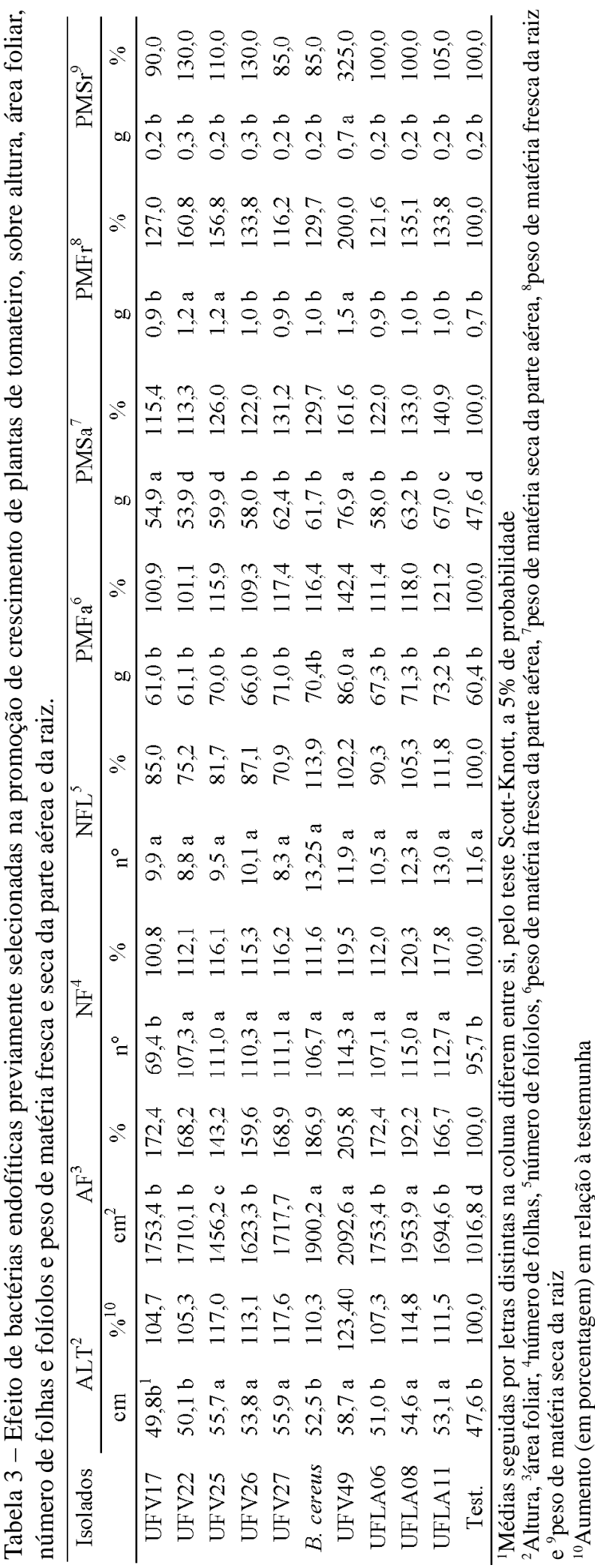

\section{Detecção de atividade in vitro das bactérias endofíticas selecionadas sobre Ralstonia solanacearum}

Dos dez isolados submetidos ao teste para detecção de antibiose, verificou-se que somente os isolados UFV-E17 e UFLA 06-LS inibiram o patógeno desafiante (Tabela 2).

Vários mecanismos estão envolvidos na promoção de crescimento das plantas por bactérias endofíticas. Estes, porém, podem ser divididos em diretos e indiretos. Quando o estímulo do crescimento das plantas é direto, o antagonista produz fitormônios ou substâncias análogas destes reguladores de crescimento capazes de estimular o desenvolvimento das plantas (BASHAN \& HOLGUIN, 1997). Quando o estímulo é indireto, o crescimento é estimulado pela redução da população de microrganismos deletérios ou patogênicos às plantas, ou seja, pelo controle biológico de fitopatógenos, sendo este pelo antagonismo direto ou pela indução de resistência sistêmica (HALLMANN et al., 1997).

Peer \& Schippers (1989) observaram que plântulas de tomate tratadas com o isolado WCS417r de Pseudomonas sp. aumentaram tanto o crescimento das plantas quanto a população do antagonista. Segundo os autores, a densa colonização deste isolado deslocou os organismos deletérios ao crescimento das plantas. De forma semelhante, Shishido et al. (1995) verificaram que isolados endofíticos de Bacillus sp. e Streptomyces sp. estimularam o crescimento de mudas de coníferas, controlando os patógenos responsáveis pela inibição do crescimento destas plantas.

\section{Avaliação da capacidade das bactérias endofíticas selecionadas em fixar nitrogênio $\left(\mathbf{N}_{2}\right)$}

Nenhum dos dez isolados de bactérias endofíticas selecionados cresceu em meios de cultura semi-específicos para Herbaspirillum sp. e Azospirillum sp. Porém, Chanway (2001) observou que o isolado endofítico PW2-R, de $B$. polymyxa, possui atividade de nitrogenase, o que explica o crescimento de plântulas de pinheiro em condições de deficiência de nitrogênio e ausência de fixação significativa de nitrogênio rizosférico, sugerindo que outros mecanismos que não a fixação de nitrogênio estejam envolvidos na promoção de crescimento das plântulas de pinheiro.

\section{CONCLUSÕES}

Cinqüenta e três isolados de bactérias endofíticas agiram como promotores de crescimento de plantas de tomateiro, sendo que o isolado UFV-E49 promoveu o maior 
crescimento, propiciando maior altura, área foliar, número de folhas e peso da matéria fresca e seca, tanto da parte aérea quanto da raiz.

Os resultados negativos para a fixação de nitrogênio e inibição in vitro do crescimento de $R$. solanacearum sugerem que outros mecanismos estejam envolvidos na promoção de crescimento induzida por este isolado.

\section{REFERÊNCIAS BIBLIOGRÁFICAS}

ARSHAD, M.; FRANKENBERGER, W. T. Microbiol production of plant hormones. In: KEISTER, D. L.; CREGAN, P. B. (Eds.). The rhizosphere and plant growth. Dordrecht: Kluwer Academic, 1991. p. 327-334.

ASSIS, S. M. P.; SILVEIRA, E. B.; MARIANO, R. L. R.; MENEZES, D. Bactérias endofíticas: método de isolamento e potencial antagônico no controle da podridão negra em repolho. Summa Phytopathologica, Jaboticabal, v. 24, p. 216-220, 1998.

BARRETTI, P. B. Isolamento e seleção de bactérias endofíticas com potencialidade para o biocontrole de enfermidades do tomateiro. 2001. 38 f. Dissertação (Mestrado em Fitopatologia) - Universidade Federal de Viçosa, Viçosa, 2001.

BASHAN, Y.; HOLGUIN, G. Azospirillum-plant relationships: environmental and physiological advances. Canadian Journal of Microbiology, Ottawa, v. 43, p. 103121, 1997.

BODDEY, R. M.; DOBEREINER, J. Nitrogen fixation associated with grasses and cereals: recent results and pespectives for the future research. Fertilizers Research, v. 42, p. 241-250, 1995.

CHANWAY, C. P. Inoculation of tree roots with plant growth promoting soil bacteria: an emergying technology for reforestation. Forest Science, Bethesda, v. 43, p. 99$112,1997$.

CHANWAY, C. P. Forest Sciences Department research highlight: nitrogen fixing pine? Vancouver: University of British Columbia, 2001. Disponível em: <http:// www.forestry.ubc.ca/brchline/99dec/fs.htm>. Acesso em: 18 out. 2001.

DOBEREINER, J.; BALDANI, J. I.; BALDANI, V. L. D. Como isolar e identificar bactérias diazotróficas de plantas não leguminosas. Brasília, DF: Embrapa/SPI; Itaguaí: Embrapa/ CNPAB, 1995. $60 \mathrm{p}$.

FERREIRA, D. F. Análises estatísticas por meio do SISVAR para Windows versão 4.0. In: REUNIÃO ANUAL DA REGIÃO BRASILEIRA DA SOCIEDADE INTERNACIONAL DE BIOMETRIA, 45., 2000, São Carlos, SP. Programa e Resumos... São Carlos: UFSCar, 2000. p. 235.

FROMMEL, M. I.; NOWAK, J.; LAZAROVITS, G. Growth enhancement and developmental modifications of in vitro grown potato (Solanum tuberosum ssp. tuberosum) as affected by a nonfluorescent Pseudomonas sp. Plant Physiology, Rockville, v. 96, p. 928-936, 1991.

HALLMANN, J.; QUADT-HALLMANN, A.; MAHAFFEE, W. F.; KLOEPPER, J. W. Bacterial endophytes in agricultural crops. Canadian Journal of Microbiology, Ottawa, v. 43, p. 895-914, 1997.

HOLLIS, J. P. Bacteria in healthy potato tissue. Phytopathology, Madison, v. 41, p. 350-367, 1951.

HUREK, T.; REINOLD-HUREK, B.; MONTAGU, M. van; KELLENBERGER, E. Root colonization and systemic spreading of Azoarcus sp. strain BH72 in grasses. Journal of Bacteriology, Washington, v. 176, p. 1913-1923, 1994.

KADO, C. I.; HESKETT, M. G. Selective media for isolation of Agrobacterium, Corynebacterium, Erwinia, Pseudomonas and Xanthomonas. Phytopathology, Saint Paul, v. 60, p. 969-976, 1970.

KIJIMA, T.; YONAI, S.; OOHASHI, K.; AMAGAI, M. Process for biologically preventing dicotyledoneous plant diseases using symbiotical bacteria. USA Patent. No. 5.401.655 (03-28-1995). 1995. $12 \mathrm{p}$.

NASCIMENTO, A. S. Bactérias endofíticas no controle de Ralstonia solanacearum e Clavibacter michiganensis subsp. michiganensis em tomateiro. 1998. 91 f. Dissertação (Mestrado em Fitopatologia) - Universidade de Brasília, Brasília, DF, 1998.

NAVES, R. L.; CAMPOS, V. P.; SOUZA, R. M. Filtrados de culturas bacterianas endofíticas na motilidade, mortalidade e eclosão de juvenis de segundo estádio de Meloidogyne javanica. Fitopatologia Brasileira, Brasília, v. 29, p. 384388, 2004. 
PEER, R. van; SCHIPPERS, B. Plant growth responses to bacterization with selected Pseudomonas spp. strains and rhizosphere microbial development in hydroponic cultures. Canadian Journal of Microbiology, Ottawa, v. 35, p. 456463, 1989.

PILLAY, V. J.; NOWAK, J. Inoculum density, temperature, and genotype effects on in vitro growth promotion and epiphytic and endophytic colonization of tomato (Lycopersicon esculentum L.) seedlings inoculated with a pseudomonad bacterium. Canadian Journal of Microbiology, Ottawa, v. 43, p. 354-361, 1997.

ROMEIRO, R. S. Métodos em bacteriologia de plantas. Viçosa: UFV, 2001. 279 p.

SHISHIDO, M.; LOEB, B. M.; CHANWAY, C. P. External and internal root colonization of lodgepole pine seedlings by two growth-promoting Bacillus strains originated from different root microsites. Canadian Journal of Microbiology, Ottawa, v. 41, p. 707-713, 1995.

SILVA, J. R. C. Bactérias endofíticas no controle da mancha (Xanthomonas vesicatoria) e da pinta bacterianas do tomateiro. 2004. 160 p. Dissertação (Mestrado em Fitopatologia) - Universidade Federal de Lavras, Lavras, 2004.

STURTZ, A. V. The role of endophytic bacteria during seed piece decay and potato tuberization. Plant and Soil, Dordrecht, v. 175, p. 257-263, 1995.

VALE, F. X. R.; FERNANDES FILHO, E. I.; LIBERATO, J. R. Quant: a software for plant disease severity assessment. In: INTERNATIONAL CONGRESS OF PLANT PATHOLOGY, 8., 2003, Christ Church, New Zealand. Abstracts... Christ Church: [s.n.], 2003. p. 105. Abstract 8.18. 